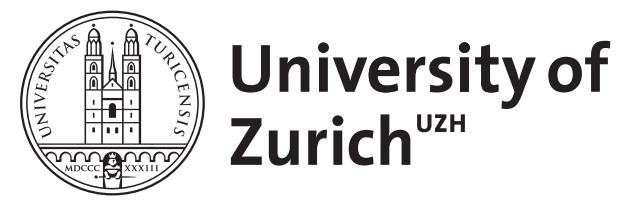

\title{
Literary role play
}

Gerber, U

\begin{abstract}
In the language classroom, most lessons about English literature tend to concentrate on the pupils' analytical faculties. This article describes one of the standard approaches and discusses its advantages and deficiencies. I then introduce a different language activity which I think appeals to the whole personality of the pupil. The response called for is analytical as well as emotional. It is a learner-oriented activity without any direct interference by the teacher. The evidence in the tapescript of a lesson shows that the activity is particularly suited for fluency practice
\end{abstract}

DOI: https://doi.org/10.1093/elt/44.3.199

Posted at the Zurich Open Repository and Archive, University of Zurich ZORA URL: https://doi.org/10.5167/uzh-154219

Journal Article

Published Version

Originally published at:

Gerber, U (1990). Literary role play. ELT Journal, 44(3):199-203.

DOI: https://doi.org/10.1093/elt/44.3.199 


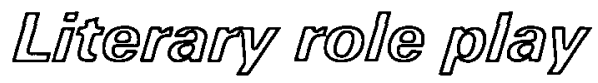 Ulrich Gerber}

In the language classroom, most lessons about English literature tend to concentrate on the pupils' analytical faculties. This article describes one of the standard approaches and discusses its advantages and deficiencies. I then introduce a different language activity which I think appeals to the whole personality of the pupil. The response called for is analytical as well as emotional. It is a learner-orientated activity without any direct interference by the teacher. The evidence in the tapescript of a lesson shows that the activity is particularly suited for fluency practice.

My reaching consers

A standard approach
Swiss pupils at pre-university level will have read quite a number of English or American plays and novels by the time they go to university and take up any subject of their own choice. Reading 'good' literature is still felt to be an integral part of any demanding English syllabus that tries to capture learners' attention, and that offers them meaningful and authentic material for reading. Literature is practically always taught not only as literature as such but also as a sort of prompt to get students to think and speak in English.

Most teachers try to depart from question-and-answer techniques, because it is hard for the teacher to keep asking genuinely open-ended questions. Students can easily feel that the teacher is directly or indirectly imposing his or her view of the text in question.

One variation of this standard approach has, however, proved very successful. In this variation, teachers get students themselves to ask questions about the text they have read. This not only gives them practice in asking relevant questions-something they will have to learn for their studies at the university in any case-but also enables them to take their own interest as the starting point for working their way into the text. The questions are then discussed in groups, with an exchange of the findings towards the end of the lesson.

When this variation of the standard approach works well, it can be very satisfying for teachers, who are always pleased to hear busy classes actually speaking the foreign language. The language arising from such work can include asking for and expressing opinions, agreeing and disagreeing, expressing personal insights, giving examples, and so on. At best, the approach does help students to deal with texts sensitively.

On the other hand, teachers who watch and listen to group work carefully will know that in group work, some students do much more talking than others: indeed some students, though well-meaning, may appear somewhat passive. Further, I have noted that the kind of activity I have 
described favours a rather intellectual approach, and does not tap the energies dormant in all my students. I wanted to give all my students opportunities for a more total and less detached response to texts, especially in those parts of lessons where we had an overall, final discussion of a text.

A differens approach

\section{Method Setting up the activity}

Step 1: An empty space is provided in the centre of the classroom.

Step 2: An (inner) circle with nine chairs is formed.

Step 3: Eight chairs are marked (with a big name tag) with an important character of the novel (Dixon, Margaret, Christine, Prof Welch, Mrs Welch, Bertrand, Carol Goldsmith and Kingsley Amis), the ninth chair is left empty-the 'Joker'.

Step 4: Eight pupils are assigned one of these roles and take a seat in the 'inner circle'. The rest of the class stand around these chairs in an outer circle.

\section{Instructions to the students}

Number 1: The pupils on the chairs are told that for the purpose of this game they have to take the roles of these characters. They are in 'Heaven', looking back on the events they experienced while living through the novel. They are expected to talk about their lives with each other.

Number 2: The pupils standing around this inner circle are informed that they can also take part in the ensuing discussion at any given moment by simply tapping on one of the characters' shoulder and taking his or her seat. They can also sit on the empty chair-the Joker-and take on the role of any other character in the novel.

The activity then starts. Once the seated pupils get started, there is no more need for the teacher to intervene or interfere with the inner circle. It may be necessary, however, to encourage pupils in the outer circle to relieve one of their colleagues. More passive students can be assigned a role and sent into the inner circle. In this way, the teacher can indirectly steer and influence the course of the talk in the inner circle. 
Results Here is a transcript of three typical extracts:

Extract one:

Teacher: I I would like you to start anywhere. You're just sitting there, together, in Heaven.

Bertrand: Well, Kingsley Amis, why did you let Christine go out from the ball with that bloody Dixon?

Kingsley Amis: Well, my intention in that was to give Dixon like another woman next to Margaret to make the story somehow interesting (general laughter) and Christine, I wanted to get some, get Dixon really into women, er, get some conflict. That's why.

Christine: $\quad$ And Dixon, why did you seduce me? (general laughter)

Dixon: Well, I just felt I had to. (pause)

Christine: But do you think it was fair?

Dixon: What was fair? (general laughter)

Christine: $\quad$ to seduce me. I mean my boyfriend's Bertrand.

Dixon: $\quad$ So what? Look at this bearded art maniac. (general laughter) He doesn't deserve you, or you don't deserve him, whatever you want to put it. I felt that I was just kind of the right guy for you. (general laughter)

Prof Welch: You weren't very fair against Margaret. You were the boyfriend of Margaret.

Dixon: $\quad$ Well, she didn't want to sleep with me in the first place. (general laughter)

Extract two:

Mrs Welch (boy imitates old woman's voice):

But Dixon, what did you make with my blankets, my sheets?

Dixon: $\quad Y o u$ see, I was in the pub till eleven, twelve o'clock, and then I went home and $\mathrm{Mr}$ Welch was in the bathroom so I went to bed and smoked a cigarette. Then I slept and ... eingeschlafen (prompt by other pupil: fell asleep) ... fell asleep. And in the morning I saw...

Mrs Welch: Didn't you lit off your cigarette?

Dixon: $\quad$ No, I didn't. I was pissed, you see. And in the morning I saw the table, burnt edge, and blankets, the hole, and, well, didn't know what to do.

Extract three:

Carol Goldsmith (to Mrs Welch):

You aren't so important in the story.

Mrs Welch: I'm very important in the story. But the problem is (general laughter) if ...er, what?

Dixon: You're the brain of Mr Welch. (laughter)

Joker:

Professor Welch, I'm the car of you. (general laughter) Why did you treat me so miserable?

Prof Welch: Well, I think it's quite hard to drive a car and ... 
Car:

Dixon:

Prof Welch: Yes, well, I think it's your fault when you sit on the spring.
Evaluation of the role play

Methodological advantages

Linguistic advantages

Dealing with mistakes
In the following, I shall point out some of the advantages of this activity, referring to the evidence in the transcript where possible.

- There is no direct teacher intervention. Once the pupils grasp the idea, the activity keeps going 'automatically' for a whole lesson. Students help each other to formulate what they want to say.

-The atmosphere is very relaxed. There is frequent laughter and merriment.

- There is genuine interaction among the pupils.

- Student participation is extremely high. With the exception of one pupil, everybody took part. Even normally very passive pupils were prepared to put themselves forward spontaneously. There was a high turnover of pupils adopting the same role.

- The characters ask each other about the motivations behind their actions in the story. The presence of the author is very stimulating. Pupils discuss the importance and the functions of the characters in the story.

- The Joker (empty seat) is important. It is a means of ensuring the constant influx of new and unforeseen ideas to which pupils have to respond spontaneously. It allows for creativity and inventiveness (for example, Prof Welch's car) and calls for even more rotation among the participants.

- The English is more natural and more real than can normally be heard in a classroom. Pupils ask follow-up questions for clarification.

- The whole style is closer to colloquial English. There is variety in the registers used, from formal, standard English to 'bloody Dixon' right through to 'I was pissed' (i.e. I was drunk).

-The students speak fluently and actively use words learnt from the text ('bearded art maniac', 'blankets', 'sheets', 'spring', etc.).

-A number of different speech acts occur, similar to the ones observed in the 'standard' approach above; the students (all of them) express opinions, agree and disagree, give examples, and so on.

It proved important that I had chosen some of the more fluent pupils to start with, because they had to trigger off the discussion. The pupils in the role of 'Kingsley Amis' (the author) sometimes had a hard time, because he was not spared any tricky questions. The participants increasingly seemed to realize that by taking part in this role play they were actually talking about and virtually experiencing the special effects resulting from the plot and the point of view of the narrative.

Of course, the students made mistakes ('Didn't you lit off your cigarette?' etc.) and I was able to note these down for further language practice. But 
I feel that a discussion of a literary work is not the time for systematically insisting on linguistic accuracy. What counts is the quality and quantity of the communication between the pupils, and these are what this activity has helped to practise.

Students' reactions In the class discussion afterwards, students unanimously said that it was a most enjoyable activity. They liked the completely different approach and the fact that it gave them a framework within which they were able to respond as they pleased. In particular, less talented actors were able to make a contribution because they could choose whether they just wanted to speak the role or to act it out with mime and gesture.

Conc/usion In selecting Lucky Jim for a class reader, I opted for a novel that is linguistically complex. It is only appropriate that such a text should be scrutinized thoroughly. An activity like the standard approach, as described at the beginning of this article, serves this purpose well, yet the method of intellectual analysis clearly has its deficiencies. That is where the literary role play can add a new dimension to the foreign language classroom. It involves the pupils emotionally and prompts them to use more natural language. The literary role play is best employed for fluency practice. It does not replace other ways of dealing with literature in the language classroom (see Collie and Slater, 1987) but forms a useful addition to the repertory of the foreign language teacher.

To sum up the basic idea, there is an 'inner circle' of pupils who are performing a linguistic task without any direct intervention by the teacher. The pupils in the 'outer circle' replace or relieve the participants in the inner circle. It is clear that this kind of set-up can be applied to other areas of teaching English literature, such as teaching plays (Gerber, 1990) and poems.

Received January 1990

\section{Note}

1 My school is a gymnasium: a selective state school at which students have to take at least eleven subjects up to the final exam, the matura, which entitles them to study any of these eleven subjects at university.

\section{References}

Collie, J., and S. Slater. 1987. Literature in the Language Classroom Cambridge: Cambridge University Press.

Gerber, U. 1990. 'A Good Way to Use Plays in the Classroom' The English Teaching Forum April 1990. Washington: United States Information Agency.
Klippel, F. 1983. Ideas Dortmund: Verlag Lambert Lensing.

Klippel, F. 1985. Keep Talking Cambridge: Cambridge University Press.

\section{The author}

Ulrich Gerber has been teaching English at pre-university level in Switzerland for fifteen years. In 1977 he received his lic. phil. (licentiate) from Zürich University. He now teaches at the Kantonsschule Zürcher Unterland in Bülach. The ages of his students range from 15 to 19 . He is interested in finding more efficient and interesting ways of teaching English. 